УДК $551.77,550.93,621.039 .86$

\title{
НОВЫЕ ДАННЫЕ ПО ВОЗРАСТУ УГЛЕНОСНЫХ ОТЛОЖЕНИЙ ЮГО-ЗАПАДНОГО ПРИМОРЬЯ И ИХ ЗНАЧЕНИЕ ДЛЯ СТРАТИГРАФИИ КАЙНОЗОЯ ДАЛЬНЕВОСТОЧНОГО РЕГИОНА
}

\author{
Чащин Александр Адольфович1, \\ achashchin@mail.ru
}

\author{
Павлюткин Борис Иванович 1 , \\ pavlyutkin@fegi.ru
}

\author{
Чекрыжов Игорь Юрьевич ${ }^{1}$, \\ chekr2004@mail.ru
}

\author{
Хубанов Валентин Борисович2, \\ khubanov@mail.ru \\ Цуцуми Юкиясуз3, \\ ytsutsu@kahaku.go.jp \\ Чащин Сергей Александрович1, \\ s.cha@fegi.ru \\ 1 Дальневосточный геологический институт ДВО РАН, \\ Россия, 690022, г. Владивосток, пр. 100-летия Владивостоку, 159. \\ 2 Геологический институт СО РАН, \\ Россия, 670047, г. Улан-Удэ, ул. Сахьяновой, 6 а. \\ 3 Национальный музей природы и науки, \\ Япония, 305-0005, префектура Ибараки, 4-1-1 Амакубо, Цукуба.
}

\begin{abstract}
Актуальность исследования обусловлена необходимостью устранения существующих расхождений во взелядах на возраст палеогеновых промышленно-угленосных отложений на юго-западе Приморья и сопредельных территориях.

Цель: осуществить U-Pb-датирования цирконов из третичных образований, встречающихся в пределах Хасанской рифртогенной впадины, что позволит в дальнейшем уточнить схему последовательности их формирования на территории югозападного Приморья.

Объекты: осадочные породы хасанской и назимовской свит, а также риолиты краскинского комплекса.

Методы. Изучение зональности и внутренней структуры цирконов выполнено электронным микрозондом JXA-8100, оснащенным катодолюминесцентным детектором, U-Pb-изотопные исследования цирконов были проведены LA-ICP-MS-методом. Результаты. Согласно полученным результатам U-Pb-датирования цирконов из третичных образований Хасанской впадины, установлено, что возраст самой молодой популяции цирконов в песчаниках назимовской и хасанской свит составляет 37-38 млн лет, что соответствует позднему эоцену и совпадает с возрастной оценкой формирования этих свит, полученной ранее по результатам изучения микро- и макрофрлоры. Установлено, что поступление цирконов самой молодой популяции в песчаники хасанской (=назимовской) свиты связано с размывом верхнеэоценовых кислых пород краскинского комплекса. Соответственно, это позволяет говорить об одновозрастности вышеперечисленных стратонов и наличии в пределах Хасанской депрессии в кайнозое одного, позднеэоценового, этапа углеобразования, а не двух, как считалось ранее. Это значительно упрощает региональную стратиграфическую шкалу применительно к Хасанской впадине и ее аналогам в других впадинах Приморья и соседних регионах юга Дальнего Востока России.
\end{abstract}

\section{Ключевые слова:}

U-Pb-датирование цирконов, кайнозой, Хасанская впадина, юго-западное Приморье, угленосные отложения, стратиграфия.

\section{Введение}

При разработке региональных стратиграфических схем (РСС) у геологов и палеонтологов нередко возникают расхождения во взглядах на возраст конкретных стратиграфических подразделений (стратонов). Это в полной мере относится и к палеогеновому стратиграфическому уровню на территории Приморья. Поскольку здесь находятся стратотипы большинства подразделений палеогена для всего континентального юга Дальнего Востока России, указанная проблема приобретает более широкий, трансрегиональный ха- рактер. В случае возникающих противоречий важную роль при их разрешении играют данные радиоизотопного определения возраста пород, полученные различными методами, в частности, с использованием $\mathrm{U}-\mathrm{Pb}$-датирования по цирконам. Так, например, в Приморье этот метод уже был успешно использован при решении вопроса о возрасте богопольской и тадушинской свит, распространенных на востоке Сихотэ-Алиня. Обе свиты относились прежде к раннему палеоцену, однако данные радиоизотопного датирования вулканитов богопольской свиты стимулирова- 
ли ревизию состава тадушинской флоры, в результате чего время ее существования, как и возраст самой свиты, сместились в интервал позднего палеоцена [1].

В данной статье изложены первые результаты радиоизотопного U-Pb-датирования цирконов из третичных образований Хасанской впадины, столь необходимые при решении весьма дискуссионной проблемы возраста палеогеновых промышленноугленосных отложений на юго-западе Приморья и сопредельных территориях.

\section{Краткий исторический экскурс}

Палеоген-неогеновые угленосные отложения на юго-западе Приморья локализованы в ряде кайнозойских впадин, но лучше всего они изучены в Хасанской (=Краскинской) депрессии (рис. 1, А, Б). Хасанские угли стали известны промышленникам, геологам и военным морякам еще в начале XX в. Наибольший вклад в изучение угленосных отложений на первом этапе (1940-е гг.) внес Г.М. Власов. Вначале они рассматривались им в составе одной свиты - хасанской, позднее им же была выделена более древняя, нази- мовская свита, также угленосная. Стратотипический разрез последней был описан на п-ове Посьет (=Новгородский) (рис. 1, Б, Г), а типовой местностью хасанской свиты считалась территория, прилегающая с севера к бухте Экспедиции (рис. 1, Б, В).

Возраст хасанской свиты изначально рассматривался в Региональных стратиграфических схемах юга Дальнего Востока как отвечающий позднему эоцену, а назимовской - интервалу поздний палеоцен - ранний эоцен $[3,4]$. Несмотря на ограниченное распространение, назимовская свита традиционно играла роль одного из ключевых стратонов кайнозойского комплекса в регионе. Это объясняется тем, что Хасанская впадина была единственной структурой на юге Приморья, где предполагалось наличие палеоцена. Следует подчеркнуть, что вывод о палеоценэоценовом возрасте назимовской свиты основывался её автором Г.М. Власовым преимущественно на стратиграфических взаимоотношениях (отчасти предполагаемых) с другими подразделениями общего разреза кайнозоя в Хасанской депрессии.
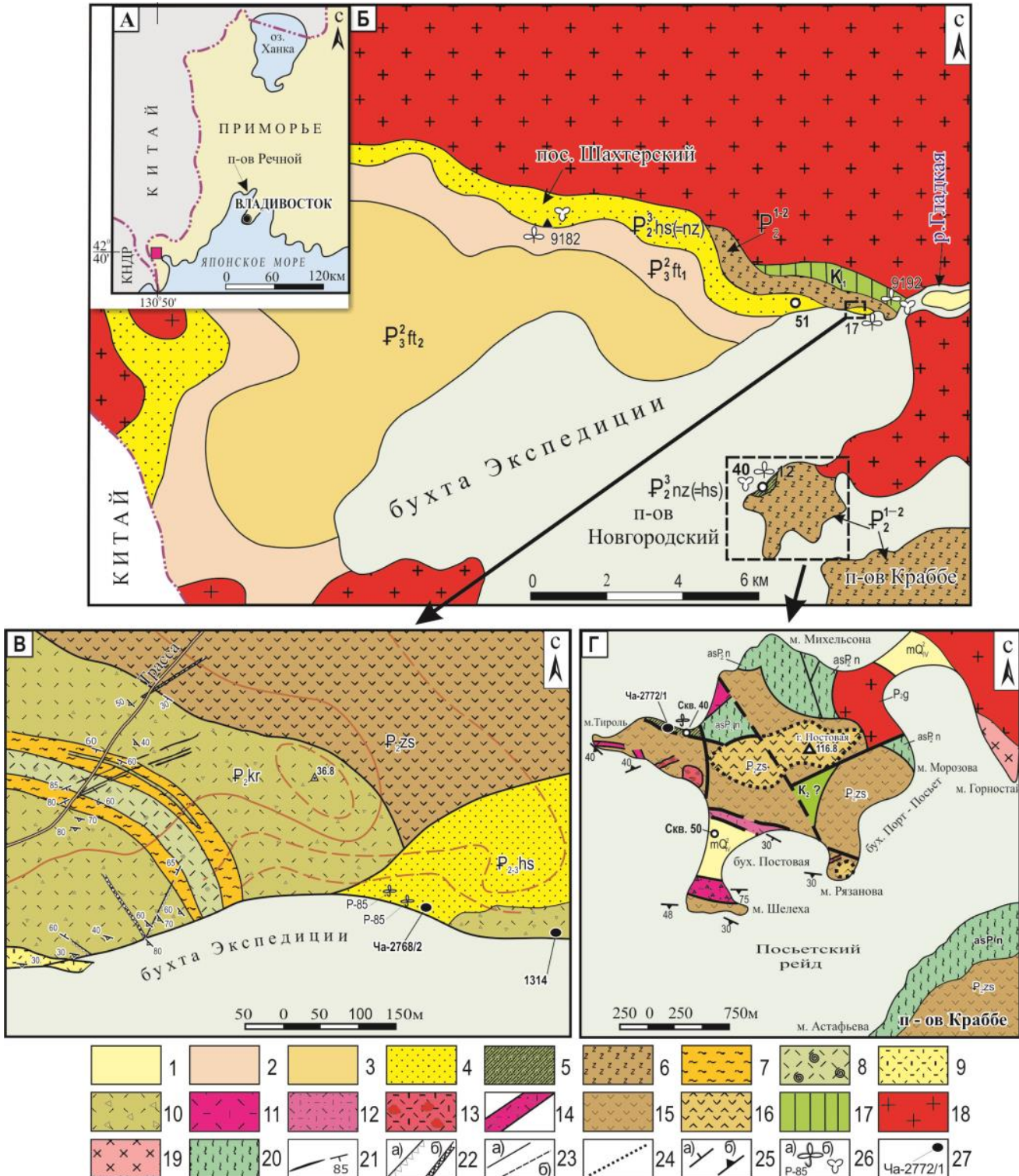
Однако принятые взаимоотношения даже на тот момент времени не соответствовали имеющимся палеоботаническим данным. Небольшой комплекс ископаемых растений из стратотипа назимовской свиты (коллекция Г.М. Власова), согласно изучившей его М.О. Борсук, отражал эоценовый (без более дробного подразделения) этап флористической сукцессии в регионе. К сожалению, заключение о возрасте назимовской флоры не было должным образом учтено. За основу были приняты вышеупомянутые взаимоотношения с подстилающими и перекрывающими стратонами. Согласно им, нижняя граница назимовской свиты с подстилающими кислыми эффузивами позднемелового-палеоценового возраста (новопосьетская свита, по Г.М. Власову) установлена в её стратотипе на пове Посьет, а верхняя - с якобы перекрывающими основными эффузивами зайсановской свиты - зафиксирована в устье р. Гладкой (рис. 1, Б, В). Тип взаимоотношения андезибазальтов и подстилающих осадочных отложений в устье р. Гладкой был автоматически перенесен на геологическую ситуацию на п-ове Посьет, где для такой операции не было оснований. В этом и заключалась главная ошибка, поскольку позднее выяснилось, что осадочная толща в устье р. Гладкой (рис. 1, Б, т. 9192), принятая за палеогеновую назимовскую свиту, содержит комплекс растительных макро- и микрофоссилий раннемелового возраста [5] и потому не может быть к ней отнесена.

Согласно более поздним исследованиям, основанным на изучении кернов специально пробуренной скважины 40, назимовская свита в стратотипическом разрезе залегает на риолито-дацитовых агломерато- вых туфах, подстилаемых палеозойскими габброидами. Проблема взаимоотношения ее с зайсановскими эффузивами детально рассмотрена ранее [6]. Установлено, что назимовская свита в одних разрезах прислонена к основным эффузивам, в других - между ними вклиниваются кислые лавы и туфы, но она нигде не перекрывается вулканитами, как считалось прежде [4]

Анализ спорово-пыльцевых спектров из кернов скв. 40 выявил их сходство со спектрами верхнеэоценовой усть-давыдовской свиты в ее стратотипе на пове Речной (рис. 1). Полученные данные позволили предложить более простой и логичный вариант локальной стратиграфической схемы для кайнозоя Хасанской впадины [7]. В ней угленосные назимовская и хасанская свиты, ранее считавшиеся разновозрастными, помещены на один стратиграфический уровень (верхний эоцен), причем как единый стратон. За ним предложено сохранить название хасанская как более раннее и потому приоритетное, а назимовскую считать поздним синонимом. Согласно последним представлениям, хасанская (=назимовская) свита залегает с несогласием на образованиях широкого геохронологического диапазона от палеозойских гранитов до меловых осадочных пород и кайнозойских риолитов краскинского комплекса. Перекрывается она без признаков стратиграфического перерыва и несогласия глинисто-туффитовой толщей (=нижнефаташинской подсвитой), охарактеризованной раннеолигоценовой флорой Краскино (т. 9182). Разрез палеогена в Хасанской впадине завершает верхнефаташинская подсвита преимущественно песчаникового состава [7].

Рис. 1. Схема расположения объекта изучения (A); схематическая геологическая карта восточного сектора Хасанской впадины (Б); план геологического строения экструзивного тела риолитов краскинского комплекса и хасанской свиты (B); геологическое строение п-ова Новгородский (Г) по [2] (с изменениями и дополнениями). 1 - четвертичные аллювиальные отложения; 2, 3 - отложения нижней подсвиты (2) и верхней подсвиты (3) фаташинской свиты (ft); 4 - эоценовые вулканогенно-осадочные отложения хасанской свиты (hs); 5 - эоценовые вулканогенно-осадочные отложения назимовской свиты (nz); 6 - нерасчлененные эоценовые вулканогенные образования; 7-13 - эоценовые эффузивы краскинского комплекса $(\mathrm{kr})$ : 7 - измененные перлиты, 8 - стекла риолитов, 9 - флюидальные риолиты, 10 - кластолавы риолитового состава, 11 - дайки риолитов и риодацитов, 12 - туфы риолитов, 13 - эруптивные брекчии; 14 - туфы риолитов новопосьетской свиты (?); 15, 16 - эоценовые вулканиты зайсановского комплекса (zs): 15 - андезиты, 16 - андезидациты; 17 - нижнемеловые отложения гладкинской толщи; 18, 19 - граниты (18) и диориты (19) пермского возраста; 20 -метаморфические породы фундамента; 21 - квариевые прожилки и их элементы залегания; 22 - тектонические разломы (а) и зоны дробления (б); 23 - разломы установленные (а) и предполагаемые (б); 24 - фациальные границы между андезитами и андезидачитами; 25 - ориентировки падения слоев (a) и флюидальности (б); 26 - местонахождения находок ископаемых растений (a) и места отбора проб для спорово-пыльцевого анализа (б); 27 - пункты отбора проб на радиоизотопный анализ и их номера

Fig. 1. Geographic location of the object under study (A); geological sketch map of the eastern sector of the Khasan depression (B); scheme of geological structure of the extrusive rhyolites of the Kraskinsky complex and the Khasan formation (C); geological structure of Novgorodsky Peninsular $(D)$ (after [2] with some modifications and additions). 1 -Quaternary alluvial sediments; 2, 3 - lower (2) and upper (3) units of the Fatashinskaya formation (ft); 4 Eocene volcanoclastic sedimentary rocks of the Khasan formation (hs); 5 - Eocene volcanoclastic sedimentary rocks of the Nazimova formation (nz); 6 - unbroken Eocene volcanogenic formations; 7-13-Eocene effusive rocks of the Kraskinsky complex (kr): 7 -altered perlites; 8 -rhyolitic glasses; 9 - rhyolites with fluidal texture, 10 - rhyolitic clastolavas, 11 -dykes of rhyolite and dacite, 12 - rhyolitic tuffs, 13 - eruptive breccias; 14 - rhyolitic tuffs of Novoposietskaya formation; 15 - andesite; 16 - andesidacite; 17 -lower Cretaceous deposits of the Gladkinskaya formation; 18, 19 - Permian granites (18) and diorites (19); 20 - metamorphic basement rocks; 21 - quartz veinlets and their attitude parameters; 22 - tectonic faults $(a)$ and shatter zones $(b) ; 23$ - established $(a)$ and potential $(b)$ faults; 24 - facies boundaries between andesites and andesidacites; 25 - orientations of beds' dip (a) and lava flow (b); 26 - sites of fossilized flora (a) and sampling for sporo-pollen analysis (b); 27 - points of sampling for radioisotopic analysis and sample numbers 
Тем не менее после публикации предложенная стратиграфическая схема вызвала весьма скептическое отношение к ней вплоть до отвержения со стороны многих геологов на региональном уровне обсуждения. Это вполне понятно, ибо прежняя схема, несмотря на всю ее противоречивость, неизменно считалась безальтернативной на протяжении многих десятилетий. Таким образом, в настоящей работе представлены первые результаты U-Pb-датирования (LA-ICP-MS методом по цирконам) отложений из стратотипа назимовской свиты на п-ове Посьет и гипостратотипа хасанской свиты (северный сектор побережья бухты Экспедиции), а также риолитов краскинского комплекса, позволяющие устранить существующие расхождения во взглядах на их возраст.

На сегодняшний день в геологической литературе при описании одних и тех же кайнозойских отложений юго-западного Приморья нередко используются разные названия одних и тех же свит, что вносит определенную путаницу и мешает читателям правильно воспринимать опубликованный материал. Аналогичная ситуация наблюдается также и в отношении некоторых тектонических структур. В этой связи авторы статьи посчитали необходимым уточнить, что здесь и далее при анализе полученных результатов они будут максимально придерживаться первоначальных названий свит и их ареалов, закрепленных в официально принятой стратиграфической схеме кайнозойских отложений юга Дальнего Востока [4].

\section{Методы и объекты исследования}

Основными объектами наших изотопногеохронологических исследований (U-Pb метод датирования) стали цирконы из песчаников хасанской (проба Ча-2768/2) и назимовской свит (проба Ча2772/1), развитых в пределах Хасанской впадины. Кроме того, было выполнено U-Pb-датирование цирконов из риолитов краскинского комплекса (проба 1314), поскольку последние могли быть наиболее вероятным источником поступления молодых цирконов в песчаники вышеназванных свит. Места отбора проб указаны на рис. 1.

Выделение кристаллов циркона из изученных пород осуществлялось по стандартной методике с использованием магнитного сепаратора и тяжелых жидкостей. Затем из образцов вручную под бинокуляром был осуществлен отбор зерен циркона, которые помещались в эпоксидную смолу и полировались с использованием алмазных паст (9 и $1 \mu \mathrm{m})$. В дальнейшем с помощью электронного микрозонда JXА8100 , оснащенного катодолюминесцентным детектором, было выполнено изучение зональности и внутренней структуры полированных цирконов, а также выбраны точки для проведения изотопных измерений. Следует отметить, что U-Pb-изотопные исследования цирконов были проведены LA-ICP-MS-методом в разных лабораториях.

Так, выбранные для U-Pb-датированиия кристаллы циркона из пробы песчаников хасанской свиты были изучены в лаборатории аналитической химии ДВГИ ДВО РАН (г. Владивосток) на масс-спектрометре с индуктивно связанной плазмой Agilent 7500a, соединенном с системой лазерной абляции пробы UP-213. Основные особенности методики описаны в работе [8]. Одновременно методом лазерной абляции (LASF-ICP-MS) проводилось U-Pb датирование цирконов из пробы песчаников назимовской свиты в ЦКП «Геоспектр» Геологического института СО РАН (г. Улан-Удэ) по методике, изложенной ранее [9]. Изотопное исследование цирконов из риолитов краскинского комплекса осуществлялось с применением метода лазерной абляции ICP-MS в Национальном музее Геологии и Палеонтологии (г. Цукуба, Япония) по методике, принятой в [10].

В процессе исследований из каждого образца было датировано от 16 до 70 кристаллов циркона. Причем возраст проанализированных кристаллов, как правило, распределен в довольно широком диапазоне. Для наших исследований наибольший интерес представляют датировки наиболее молодой популяции цирконов, поскольку возраст вмещающих отложений, естественно, не может быть древнее этой группы.

\section{Результаты и их обсуждение}

Как отмечалось ранее, возраст образований назимовской и хасанской свит основан преимущественно на результатах изучения комплекса растительных остатков в разрезах осадочных пород. Радиоизотопное датирование вышеперечисленных стратонов не осуществлялось, что не позволяет обосновать возрастной диапазон их формирования. В этой связи был выполнен анализ U-Pb-датирования цирконов, выделенных из представительных проб песчаников из стратотипических разрезов назимовской и хасанской свит (п-ов Посьет и северное побережье бухты Экспедиции соответственно).

Назимовская свита. Для U-Pb геохронологических исследований цирконов отобран образец среднезернистых песчаников из нижней части стратотипического разреза назимовской свиты, обнажающейся в береговых обрывах северной стороны мыса Тироль. Из пробы выделено 50 кристаллов, которые были проанализированы LA-SF-ICP-MS-методом в лаборатории Геологического института СО РАН (г. УланУдэ). Изотопное исследование показало, что в изученном образце присутствуют четыре разновозрастные популяции цирконов, отвечающие интервалам (млн лет) 262-267, 243-250, 203-210 и 37-46.

Наиболее древняя популяция цирконов, имеющая пермский возраст (262-267 млн лет), представлена идиоморфными кристаллами длиннопризматического, реже короткопризматического облика, размером 300 $\mu \mathrm{m}$. Катодолюминесцентное изображение этих цирконов показывает, что некоторые из них обладают хорошо выраженной зональностью. Величина Th/Uотношения варьирует в них в довольно узком диапазоне от 0,46 до 0,50.

Цирконы раннетриасового возраста (243-250 млн лет) по морфологии и внутреннему строению кристаллов практически не отличаются от цирконов позднетриасового возраста, но имеют при этом более низкие значения Th/U-отношения - 0,33-0,54. 

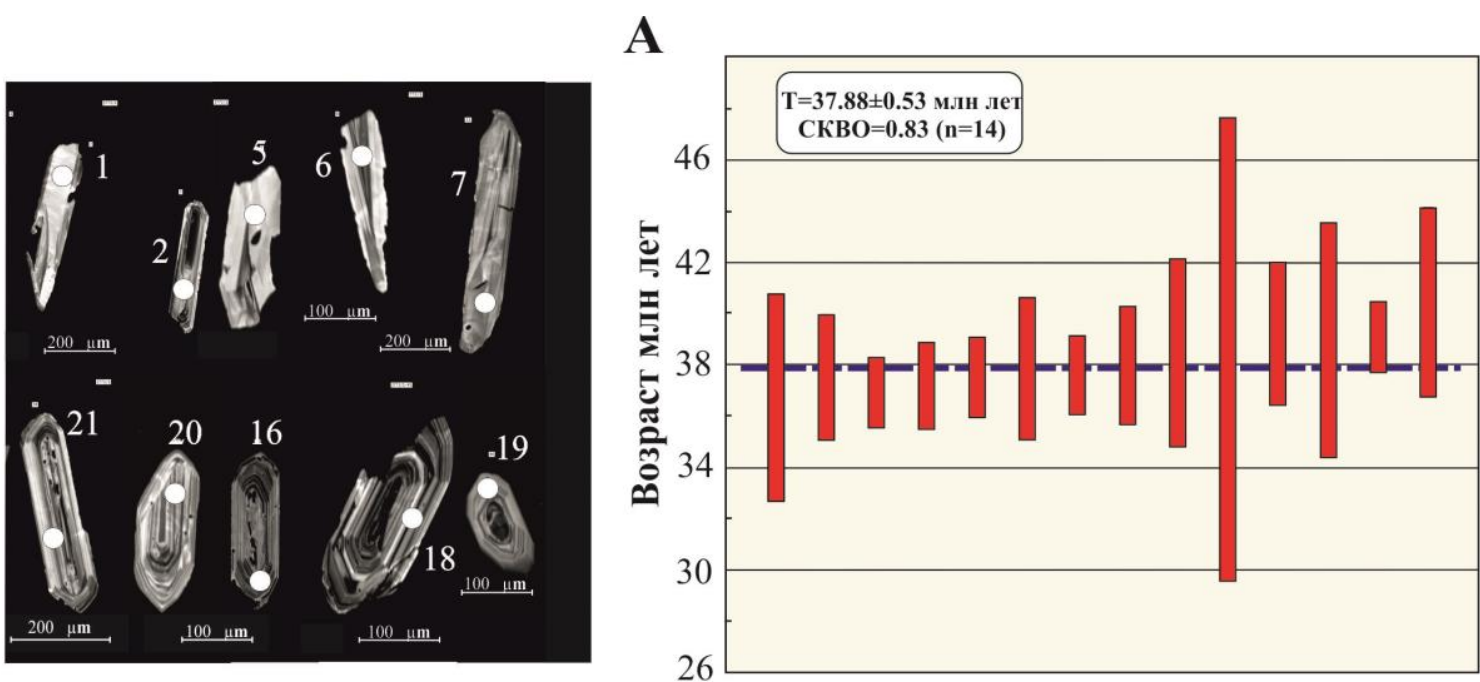

Б
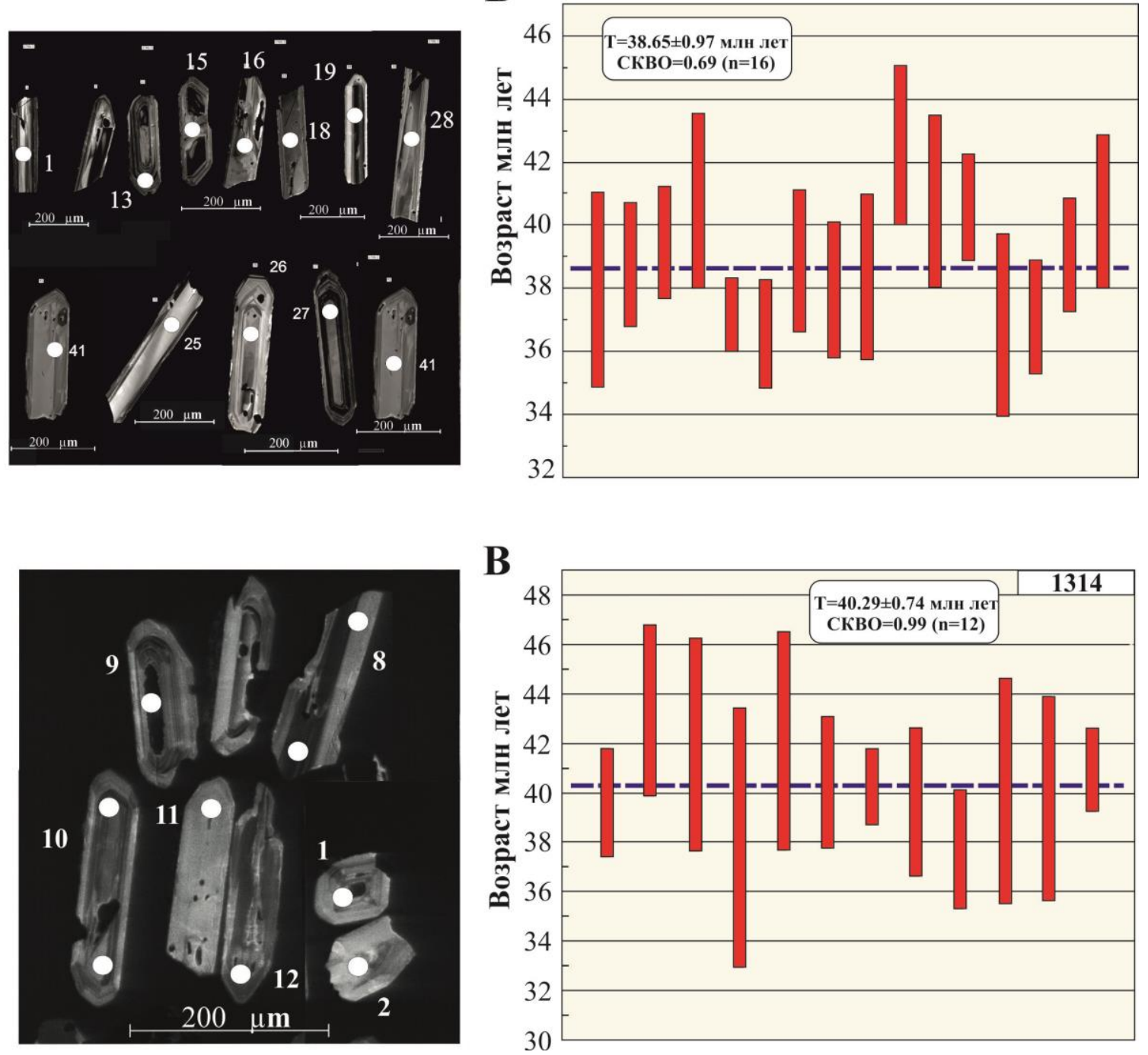

Pис. 2. Катодолюминесиентные изображения и диаграммы средневзвешенных возрастов для иирконов из пород Хасанской впадины: А) из песчаника назимовской свиты (обр. Ча- 2772/1); Б) из песчаника хасанской свитьл (обр. Ча-2768/2); В) из риолита краскинского комплекса (обр. 1314)

Fig. 2. Cathodoluminescence images of zircons and diagrams of the weighted average ages of zircons from rocks of the Khasan depression: A) sandstones of the Nasimova formation (smpl. Ya-2772/1); Б) sandstones of the Khasan formation (smpl. Ya-2768/2); B) rhyoloites of the Kraskinsky comples (smpl. 1314) 
Следующая возрастная популяция цирконов, имеющая позднетриасовый возраст (203-210 млн лет), представлена четырьмя кристаллами удлиненно призматической формы размером 100-400 $\mu \mathrm{m}$, имеющими плохо выраженную зональность. Величина $\mathrm{Th} / \mathrm{U}$ отношения в этих цирконах составила $0,54-1,10$. Средневзвешенный возраст, рассчитанный по четы-

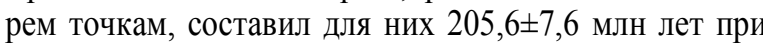
$\mathrm{CKBO}=1,7$. Отметим, что возраст этих цирконов близок к диапазону возрастов цирконов (233-204 млн лет) из вулканитов тальминского комплекса, распространенного в южной части Хасанской впадины [11].

Цирконы самой молодой популяции представлены мелкими ( 50-250 $\mu \mathrm{m})$ длиннопризматическими, реже короткопризматическими, прозрачными кристаллами бледно-розовой окраски, а также их обломками. В целом среди изученных цирконов преобладают идиоморфные неокатанные зерна. В катодолюминесцентном излучении отдельные зерна минерала обладают хорошо выраженной тонкой осцилляторной магматической зональностью. Величина Th/U отношения в изученных кристаллах достигает значений 0,47-1,36, типичных для цирконов магматического генезиса. Средневзвешенный изотопный возраст для данной популяции цирконов, рассчитанный по 14 точкам, составил $37,88 \pm 0,53$ млн лет при $(\mathrm{CKBO}=1,7)$ что соответствует примерно границе средний/поздний эоцен по Международной Стратиграфической Шкале (МСШ). Таким образом, возраст песчаников назимовской свиты, вмещающей данные цирконы, не может быть существенно древнее позднего эоцена. Это значительно расходится с оценкой времени формирования назимовской свиты (поздний палеоцен - ранний эоцен), закрепленным в [4] и принятым при геологосъемочных работах (ГДП-200) [12]

Хасанская свита. Для проведения геохронологического исследования взята объемная проба среднезернистых песчаников из нижней части разреза хасанской свиты, обнажающейся в береговых обрывах бухты Экспедиции, вблизи устья р. Гладкой. Из пробы выделено 26 кристаллов циркона, U-Pb-датирование которых проводилось LA-ICP-MS-методом в лаборатории аналитической химии ДВГИ РАН.

В процессе исследования была выявлена всего одна возрастная популяция цирконов, имеющая узкий разброс индивидуальных дат - от 37 до 46 млн лет. Цирконы представляют собой прозрачные кристаллы хорошей сохранности, имеющие длиннопризматический, реже короткопризматический, облик с размером по длинной оси от 100 до $400 \mu \mathrm{m}$. У отдельных индивидов просматривается хорошо выраженная тонкая осцилляторная зональность. Величина $\mathrm{Th} / \mathrm{U}$ отношения в изученных цирконах варьирует от 0,70 до 1,9. Средневзвешенный изотопный возраст цирконов хасанских песчаников, рассчитанный по 16 кристаллам, составляет 38,65 $\pm 0,97$ млн лет $(\mathrm{CKBO}=0,69)$, что соответствует нижнему пределу времени завершения осадконакопления. Этот результат вполне согласуется с оценкой возраста отложений назимовской и хасанской свит, по палеоботаническим данным (не древнее позднего эоцена) [6].
Что касается верхнего возрастного предела обеих свит, то необходимо указать, что возраст глинистотуффитовой толщи (=фаташинской свиты), перекрывающей без видимого несогласия и стратиграфического перерыва хасанскую свиту, отвечает раннему олигоцену (ранний рюпель) на основании детально изученной флоры Краскино, содержащей уникальный комплекс растений узкого стратиграфического диапазона [7]. Ее аналоги изучены на территории севера Кореи (флора Kungshim) и Японии. Так, на северовостоке о-ва Хоккайдо ей соответствует флора Wakamatsuzawa. Возраст дацитов из одноименной формации - 31,4 и 32,6 млн лет (K-Ar метод), при том что возраст нижних слоев подстилающей угленосной формации Harutori - 38,6 млн лет (метод треков) [13, 14]. На территории США, в Орегоне, уровню флоры Краскино отвечает флора Bridge Creek. Для соответствующей формации John Day получены даты 32,2 и 33,6 млн лет $\left({ }^{40} \mathrm{Ar}-{ }^{39} \mathrm{Ar}\right.$ метод) [15]. Близкие по составу палеофлоры и спорово-пыльцевые спектры описаны для раннего олигоцена в Южном и Юго-Западном Китае [16, 17]. Следовательно, верхний возрастной уровень хасанской свиты соответствует примерно эоцен/олигоценовой границе.

Как отмечалось выше, выполненное ранее палинологическое изучение хасанской и назимовской свит по разрезам, приуроченным к двум секторам впадины - южному (п-ов Посьет, скв. 40) и северному (устье р. Гладкая, скв. 129), указывает на таксономическое и композиционное сходство споровопыльцевых спектров из обоих разрезов [6]. В них преобладают покрытосеменные (55-75 \%) над голосеменными (20-45\%) при незначительной роли спор (менее $10 \%$ с абсолютным доминированием кочедыжниковых).

В группе голосеменных ведущее место занимают таксодиевые (15-25 \%) при подчиненной роли сосновых, в которых преобладают Pinus subg. Haploxylon и P. subg. Diploxylon (до 25 \% в сумме), а также Picea sect. Picea и P. sect. omorica. Доля пыльцы елей не превышает $10 \%$, снижаясь в отдельных пробах до 1,0-1,5\%. Постоянно присутствует Tsuga, хотя и в незначительном количестве (1,0-1,5 \%). В некоторых пробах изредка отмечается единично пыльца Ginkgo, более обычна, но также малочисленна $(<1$ \%) пыльца хвойных южного распространения (Podocarpus, Cedrus, Keteleeria, Sciadopitys).

В группе покрытосеменных доминирует (до 30 \%) пыльца ильма при незначительном участии других представителей семейства ильмовых (Zelkova, Celtis). В меньшем количестве (не более $10 \%$ ) присутствует пыльца ореховых в т. ч. Engelhardtia, березовых (Betula spp.), буковых (с пребладаением Fagus spp.) и розоцветных. Весьма показательно участие в спектрах пыльцы гамамелидовых (Corylopsis, Hamamelis, Liquidambar), предположительно вечнозеленых дубов (Quercus graciliformis, Q. conferta, Q. forestdalensis, Quercites sparsus), а также формальных таксонов из родов Triporopollenites, Tricolpopollenites, Pseudoplicapollis и некоторых других (палеоботанические определения выполнены Т.И. Петренко). Пе- 
речисленные таксоны весьма характерны для эоцена, преимущественно позднего, различных районов Востока Азии [18-22]. На территории Приморья, как уже отмечалось выше, палиноспектры хасанской свиты наиболее близки спектрам из верхнеэоценовой усть-давыдовской свиты в её стратотипе на п-ове Речной (рис. 1) [7]

Из сказанного следует, что назимовская свита на п-ве Новгородский является возрастным и литологическим аналогом хасанской свиты, развитой в северном секторе бухты Экспедиции. Кстати, к выводу о возможном более молодом, чем принято считать в [4], возрасте назимовской свиты, пришел и А.В. Можеровский, по результатам литологических исследований, отметивший, что песчаники назимовской свиты могут отвечать возрастному диапазону 33-23 млн лет [23].

Поскольку по литологическим и палеоботаническим данным хасанская и назимовская свиты однотипны, а возраста цирконов самой молодой популяции в их отложениях близки, можно говорить об одновозрастности этих стратонов. Таким образом, полученные новые радиоизотопные данные подтверждают предложенную в [7] схему последовательности формирования кайнозойского комплекса Хасанской впадины (рис. 3).

Обращает на себя внимания тот факт, что кристаллы циркона обеих свит близки между собой не только по возрасту, но и по морфологическим признакам, что указывает на их вероятное поступление в изученные песчаники из общих источников сноса. Учитывая, что цирконы молодой популяции обеих свит являются магматическими, а их кристаллы имеют хорошо сохранившуюся кристаллографическую форму, что типично для минералов, не испытавших значительного переноса и поступивших в осадок достаточно быстро после своей кристаллизации, логично предположить, что их присутствие связано с вулканизмом, который проявился синхронно с формированием изученных свит или несколько им предшествовал. Действительно, согласно существующим представлениям [2], в этот же период времени (в позднем эоцене раннем олигоцене) в пределах Хасанской впадины образуется бимодальная базальт-риолитовая серия, представленная зайсановскими базальтами и андезитами, а также краскинскими риолитами и их туфами. Вероятно, что именно кислые эффузивы краскинского комплекса могли быть основным источником поступления цирконов молодой популяции в хасанские и назимовские песчаники.

Для определения времени формирования кислых пород краскинского комплекса нами была отобрана проба кластолав риолитового состава из береговых обнажений в северной части бухты Экспедиции (рис. 1, В). Следует отметить, что по результатам бурения (рис. 1, Б, скв. 51) и наблюдениям в береговых обнажениях рассматриваемый комплекс перекрывается здесь флористически охарактеризованными слоями хасанской свиты. В дальнейшем из данной пробы было выделено 30 зерен, которые затем были использованы для U-Pb-датирования, выполненного в лабо- ратории Национального музея Геологии и Палеонтологии г. Цукуба (Япония) с применением метода лазерной абляции ICP-MS. В результате проведенных исследований выявлены две популяции цирконов с диапазонами возрастов 38-44 и 52-60 млн лет.
A

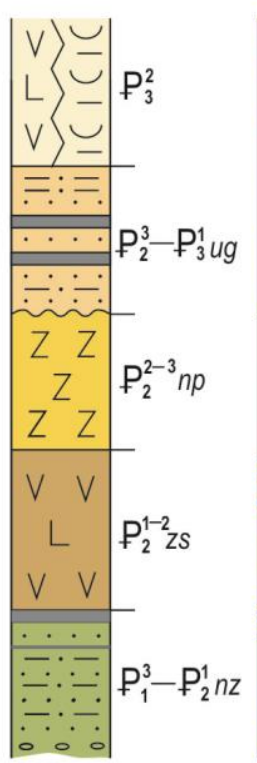

Б

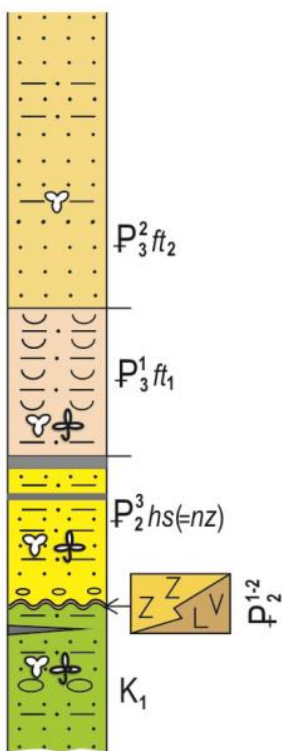

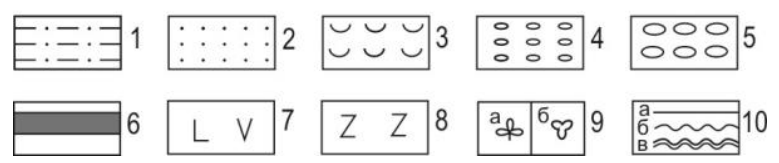

Рис. 3. Литолого-стратиграфические колонки кайнозойских образований Хасанской впадины: согласно офиииально принятой схеме [4] (А) и предлагаемая авторами (Б). Стратифицированные образования - свиты: назимовская (nz), хасанская (hs), зайсановская (zs), новопосьетская (np), угловская (ug), фаташинская (ft); 1 - алевролит, 2 - песчаник, 3 - туффит, 4 - гравийник, 5 конгломерат, 6 - уголь бурый, 7 -лавы, туфы базальтов, андезитов, 8 -лавы, туфы дацитов, риолитов, 9 - местонахождения макрофоссилий (а), проб для спорово-пыльцевого анализа (б), 10 - границы: согласные (а), несогласий (б); стратиграфические перерывы (в)

Fig. 3. Lithologostratigraphic columns of the Cenozoic sequences of the Khasan depression: according to the officially adopted scheme [4] (A), the authors' proposition (Б). Stratified formations: Nazimova (nz), Khasan (hs), Zaisanovskaya (zs), Novoposyetskaya (np), Uglovskaya (ug), Fatashinskaya (ft); 1 - siltstone, 2 - sandstone, 3 tuffite, 4 - gravel deposit, 5 - conglomerate, 6 brown coal, 7 - lava, basaltic tuff, andesite, 8 - lava, dacitic and rhyolitic tuffs, 9 - locations of microfossils (a), samples for sporo-pollen analysis (б), 10 - boundaries: conformity (a), unconformity (б), stratigraphic gaps (8)

Цирконы наиболее многочисленной молодой возрастной популяции (38-44 млн лет) представлены преимущественно удлиненно призматическими кри- 
сталлами размером от 70 до $350 \mu \mathrm{m}$. Отметим, что по своей морфологии они аналогичны цирконам молодой популяции из песчаников выше описанных свит. Величина $\mathrm{Th} / \mathrm{U}$ отношение варьирует в них в довольно широком диапазоне - от 0,69 до 1,89. В катодолюминесцентном излучении в отдельных зернах наблюдается хорошо выраженная осцилляторная зональность. Средневзвешенная возрастная датировка цирконов этой популяции по результатам LA- ICP-MS составляет 40,3 $\pm 0,7$ млн лет (по данным девяти точек) при величине $\mathrm{CKBO}=0,99$. Отметим, что данная $\mathrm{U}-\mathrm{Pb}$ датировка близка возрасту - 36,7 1,4 млн лет, полученному ранее K-Ar методом для дайки вулканического стекла риолитового состава, закартированой в бассейне р. Виноградная (приток р. Гладкой), в типовой местности краскинского комплекса [24]. Таким образом, породы краскинского комплекса имеют средне-позднеэоценовый возраст.

Кристаллы циркона второй популяции встречаются преимущественно в виде небольших обломков $(50-100 \mu \mathrm{m})$ короткопризматических кристаллов со слабо сглаженными формами, реже отмечаются идиоморфные кристаллы. Последние имеют слабо выраженную осцилляторную зональность. Величина Th/Uотношения в цирконах этой популяции варьируют в интервале 0,40-1,28. В целом подобные характеристики свойственны цирконам магматического происхождения. Средневзвешенный возраст, рассчитанный для цирконов данной популяции по восьми точкам

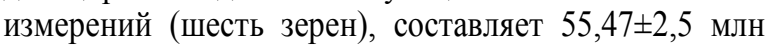
лет при величине $\mathrm{CKBO}=3,2$. Вероятней всего, эти цирконы попали в риолитовый расплав из ксеногенных обломков «рамы», захваченных в процессе его подъема к поверхности.

Исходя из полученных $\mathrm{U}-\mathrm{Pb}$ изотопно-геохронологические данных, можно обоснованно полагать, что именно кислые эффузивы краскинского комплекса поставляли цирконы средне-позднеэоценового возраста в песчаники ранее считавшихся разновозрастными назимовской и хасанской свит.

\section{СПИСОК ЛИТЕРАТУРЫ}

1. The plant biostratigraphy of the Cenozoic coal-bearing formations in Primorye, Russian Far East / B.I. Pavlyutkin, T.I. Petrenko, I.Y. Chekryzhov, V.P. Nechaev, T.A. Moore // International Journal of Coal Geology. - 2020. - V. 220. - № 103414. - P. 1-21

2. Попов В.К., Чащин А.А. Кайнозойский вулканизм рифтогенных впадин юго-западного Приморья. - Владивосток: Дальнаука, 2016. $-63 \mathrm{c}$.

3. Решения Межведомственного совещания по выработке унифицированных стратиграфических схем для Дальнего Востока - М.: Госгеолтехиздат, 1958. - 51 c.

4. Решения 4-го Межведомственного стратигрфического совещания по докембрию и фанерозою юга Дальнего Востока и Забайкалья (Хабаровск, 1990 г.). - Хабаровск, 1994. - 124 с.

5. Маркевич В.С. Альбская палинофлора Приморья // Эволюция организмов и биостратиграфия середины мелового периода. Владивосток: ДВНЦ АН СССР, 1981. - С. 116-129.

6. О возрасте палеогеновых назимовской и хасанской свит ЮгоЗападного Приморья / Б.И. Павлюткин, С.И. Неволина, Т.И. Петренко, Т.К. Кутуб-Заде // Стратиграфия. Геол. корреляция. - 2006. - Т. 14. - № 3. - С. 108-121.

7. Павлюткин Б.И., Петренко Т.И. Стратиграфия палеогеннеогеновых отложений Приморья. - Владивосток: Дальнаука, 2010. $-164 \mathrm{c}$.

\section{Заключение}

Возраст самой молодой популяции цирконов в песчаниках назимовской и хасанской свит, согласно данным U-Pb-датирования, составляет 37-38 млн лет, что соответствует позднему эоцену в пределах допуска и совпадает с возрастной оценкой формирования этих свит, полученной ранее по результатам изучения микро- и макрофлоры. Соответственно, отложения назимовской свиты, локально распространенные на пове Новгородский, и отложения хасанской свиты, развитые на остальной территории Хасанской впадины, являются одновозрастными образованиями. Следовательно, в пределах Хасанской депрессии в кайнозое был один, позднеэоценовый, этап углеобразования, а не два, как считалось ранее. Ему соответствует формирование хасанской (=назимовской) свиты.

Учитывая магматическую природу изученных цирконов, а также их морфологические особенности, можно предположить, что поступление цирконов самой молодой популяции в песчаники хасанской (=назимовской) свиты связано с размывом верхнеэоценовых кислых пород краскинского комплекса.

Таким образом, результаты радиоизотопного датирования могут быть использованы в качестве решающего дополнительного аргумента в случае принципиальных расхождений в оценке возраста ключевых стратонов, определяющих архитектуру РСС. В нашем случае речь идет о хасанской (=назимовской) свите. Имеющиеся два варианта ее положения в МСШ - официально принятый [4] и предложенный авторами - отражены в литолого-стратиграфических колонках (рис. 3). Полученные датировки свидетельствуют в пользу второго варианта. Легко видеть, насколько он упрощает РСС применительно к Хасанской впадине и ее аналогам по геологическому строению в других впадинах Приморья (Павловка, Реттиховка, Демби и др.) и в соседних регионах юга Дальнего Востока России.

Исследование выполнено при финансовой поддержке РФФИ (гранты № 21-55-53013 ГФЕН_а и № 19-05-00229A).

8. The application of laser ablation-inductively coupled plasma-mass spectrometry to in situ U/Pb zircon geochronology / S.E. Jackson, N.J. Pearson, W.L. Griffin, E.A. Belousova // Chemical Geology 2004. - V. 211. - P. 47-69.

9. Хубанов В.Б., Буянтуев М.Д., Цыганков А.А. U-Pb изотопное датирование цирконов из PZ3-MZ магматических комплексов Забайкалья методом магнитно-секторной масс-спектрометрии с лазерным пробоотбором: процедура определения и сопоставление с SHRIMP данными // Геология и геофизика. 2016. - T. 57. - № 1. - C. 241-258.

10. LA-ICP- MS and SHRIMP age of zircons in chevkinite and monazite tuffs from the Boso Peninsula, Central Japan / Y. Tsutsumi, K. Horie, T. Sano, R. Miyawaki, K. Momma, S. Matsubara, M. Shigeoka, K. Yokoyama // Bulletin of the National Museum of Nature and Science. Series C, Geology \& Paleontology. - 2012. - V. 38. - P. 15-32.

11. Новые результаты минералого-геохимических и изотопногеохронологических исследований триасового вулканизма южного Приморья (на примере изучения Тальминской вулканоструктуры) / С.А. Чащин, В.К. Попов, А.А. Чащин, С.Ю. Будницкий // IX Сибирская конференция молодых ученых по наукам о Земле. - Новосибирск, 2018. - С. 673-676.

12. Государственная геологическая карта Российской Федерации. Масштаб 1:200000. Серия Ханкайская. Листы K-52-XI, XVII. 
Объяснительная записка / под ред. Н.К. Цесарского. - М.: МФ ВСЕГЕИ, 2013. - $144 \mathrm{c}$.

13. Tanai T. Euphorbiaceae and Icacinaceae from the Paleogene of Hokkaido, Japan // Bulletin of the National Museum of Nature and Science. Series C, Geology \& Paleontology. - 1990. - V. 16. № 3. - P. 91-118.

14. Oligocene-Neogene fossil history of Asian endemic conifer genera in Japan and Korea / A. Yabe, E. Jeong, K. Kim, K. Uemura // Journal of Systematics and Evolution. - 2019. V. 57. - № 2. - P. 114-128.

15. Meyer H.W., Manchester S.R. The Oligocene Bridge Creek Flora of the John Day Formation, Oregon // University of California publications in geological sciences. - 1997. - V. 141. - $270 \mathrm{p}$.

16. Oligocene plant ecological strategies in low-latitude Asia unraveled by leaf economics / Q. Li, T. Su, Y.C. Liu, C. Quan // Journal of Asian Earth Sciences. - 2019. - V. 182. - № 103933. P. $1-10$.

17. Early Oligocene vegetation and climate of southwestern China inferred from palynology / H. Tang, S.-F. Li, T. Su, R.A. Spice, S.-T. Zhang, S.-H. Li, J. Liu, V. Lauretano, C.R. Witkowski, T.E.V. Spicer, W.-Y.-D. Deng, M.-X. Wu, W.-N. Ding, Z.-K. Zhou // Palaeogeography, Palaeoclimatology, Palaeoecology. 2020. - V. 560. - № 109988. - P. 1-10.

18. Бойцова Е.П., Панова Л.А. Палеогеновые флоры и растительность на территории Евразийской ботанико-географической области // Палинология кайнофита. - М.: Наука, 1973. - С. 42-47.

19. Climatic change during the Palaeocene to Eocene based on fossil plants from Fushun, China / Q. Wang, D.K. Ferguson, G.-P. Feng, A.G. Ablaev, Y.-F. Wang, J. Yang, Y.-L. Li, C.-S. Li // Palaeogeography, Palaeoclimatology, Palaeoecology. - 2010. V. 295. - P. 323-331.

\section{Информация об авторах}

Чащин A.A., кандидат геолого-минералогических наук, старший научный сотрудник лаборатории геохимии Дальневосточного геологического института ДВО РАН.

Павлюткин Б.И., доктор геолого-минералогических наук, ведущий научный сотрудник лаборатории региональной геологии и тектоники Дальневосточного геологического института ДВО РАН.

Чекрыж⿻в И.Ю., научный сотрудник лаборатории геохимии Дальневосточного геологического института ДВО РАН.

Хעбанов В.Б., кандидат геолого-минералогических наук, заведующий лабораторией геохронологии и геохимии окружающей среды Геологического института СО РАН.

Цуцуми Ю., исследователь Департамента геологии и палеонтологии Национального музея природы и науки.

Чащин C.A., младший научный сотрудник лаборатории геохимии Дальневосточного геологического института ДВО РАН.
Quantitative reconstruction of Middle and Late Eocene paleoclimate based on palynological records from the Huadian northeastern China: Evidence for monsoonal influence on oil shale formation / Q.-t. Meng, A.A. Bruch, G. Sun, Z.-j. Liu,
F. Hu, P.-c. Sun // Palaeogeography, Palaeoclimatology, Palaeoecology. - 2018. - V. 510 - P. 63-77.

1. Zhao Y. Vegetation and climate reconstructions on different time scales in China: a review of Chinese palynological research // Vegetation History and Archaeobotany. $-2018 .-$ V. 27. - P. 381-392. Paleogene basin evolution in relation to the left-lateral Cao BangTien Yen Fault / A. Wysocka, P.D. Pha, E. Durska, U. Czarniecka, D. Thang, A. Filipek, N.Q. Cuong, D.M. Tuan, N.X. Huyen, H.V. Tha, R. Staniszewski // Journal of Asian Earth Sciences. - V. 195. - № 104350. - P. 1-20. сьет (Южное Приморье) с минералогической точки зрения // Вестник КРАУНЦ. Науки о Земле. - 2019. - Т. 43. - № 3. C. $26-37$

- Петролого-геохимическая характеристика вулканических кайнозойских комплексов Краскинской впадины на примере ские магматические и метаморфические образования ДальнеВостока: материалы V Дальневосточного регионального петрографического совещания. - Хабаровск: ФГУГГП «Хабаровскгеология», 2001. - С. 38-40.

Поступила: 01.12.2021 2.

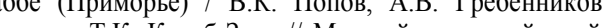


UDC 551.77, 550.93, 621.039.86

\title{
NEW DATA ON THE AGE OF COAL-BEARING STRATA IN THE SOUTHWESTERN PRIMORYE AND THEIR SIGNIFICANCE FOR CENOZOIC STRATIGRAPHY OF THE FAR EAST
}

\author{
Aleksandr A. Chashchin ${ }^{1}$, \\ achashchin@mail.ru \\ Boris I. Pavlyutkin'1, \\ pavlyutkin@fegi.ru \\ Igor Yu. Chekryzhov', \\ chekr2004@mail.ru \\ Valentin B. Khubanov², \\ khubanov@mail.ru \\ Yukiyasu Tsutsumi ${ }^{3}$, \\ ytsutsu@kahaku.go.jp

\section{Sergey A. Chashchin 1 ,} \\ s.cha@fegi.ru \\ 1 Far East Geological Institute FEB RAS, \\ 159, Prospekt 100-letiya, Vladivostok, 690022, Russia. \\ 2 Geological Institute SB RAS, \\ 6a, Sakhyanova street, Ulan-Ude, 670047, Russia. \\ 3 National Museum of Nature and Science, \\ 4-1-1 Amakubo, Tsukuba, Ibaraki, 305-0005, Japan.
}

The relevance of the research is conditioned by the need to eliminate the existing division of opinions about the age of the commercially coal-bearing Paleogene deposits in the southwestern Primorye and neighboring territories.

The main objective is to carry out U-Pb analysis of zircons from the Tertiary rocks within the Khasan rift valley for later use of these data in specifying the order of formation of the rocks.

Objects: sedimentary rocks of the Khasan and Nasimova formations, rhyolites of the Kraskinsky complex.

Methods: study on zircon internal zoning and structure with the help of cathodoluminescence detector-equipped JXA-8100 electron microprobe, U-Pb dating of zircons by LA-ICP-MS.

Results. The age of 37-38 Ma was determined for the zircons from sandstones of the Nasimova and Khasan formations. This age corresponds to the late Eocene and coincides with the age estimation of these sequences formation inferred from the previous studies on micro- and macroflora. Is has been established that the supply of the youngest population of zircons to the sandstones was due to erosion of the upper Eocene acid rocks of the Kraskinsky complex. This allows a suggestion about the uniformity of age for the above-mentioned stratigraphic units and the existence of one rather than two, as previously believed, stages of coalification in the Cenozoic within the Khasan rift valley. The new data thus considerably simplify regional stratigraphic scale as applied to the Khasan depression and its analogues in Primorye and neighboring regions.

Key words:

U-Pb dating of zircons, Cenozoic, Khasan depression, southwestern Primorye, coal-bearing strata, stratigraphy.

The research was financially supported by the RFBR (grants no. 21-55-53013 ГФEH_a, 19-05-00229A).

\section{REFERENCES}

1. Pavlyutkin B.I., Petrenko T.I., Chekryzhov I.Y., Nechaev V.P., Moore T.A. The plant biostratigraphy of the Cenozoic coalbearing formations in Primorye, Russian Far East. International Journal of Coal Geology, 2020, vol. 220, no. 103414, pp. 1-21.

2. Popov V.K., Chashchin A.A. Kaynozoyskiy vulkanizm riftogennykh vpadin yugo-zapadnogo Primorya [Cenozoic volcanism within rift valleys of the southwestern Primorye]. Vladivostok, Dalnauka Publ., 2016. 63 p.

3. Resheniya Mezhvedomstvennogo soveshchaniya po vyrabotke unifitsirovannykh stratigraficheskikh skhem dlya Dalnego Vostoka [Decisions of Inter-Agency Meeting for the development of uniform stratigraphic schemes for the Russian Far East]. Moscow, Gosgeoltekhizdat Publ., 1958. 51 p.
4. Resheniya 4-go Mezhvedomstvennogo stratigrficheskogo soveshchaniya po dokembriyu i fanerozoyu yuga Dalnego Vostoka $i$ Zabaykalya [Decisions of the 4th Inter-Agency Stratigraphic Meeting on Precambrian and Phanerozoic evolution of the south of Far East and Transbaikalia]. Khabarovsk, 1994. 124 p.

5. Markevitch V.S. Albskaya palinoflora Primorya [Albian palynoflora of Primorve]. Evolyutsiya organizmov $i$ biostratigrafiya serediny melovogo perioda [Organic evolution and biostratigraphy in the middle of the Cretaceous Period]. Vladivostok, SA USSR Publ., 1981. pp. 116-129.

6. Pavlyutkin B.I., Nevolina S.I., Petrenko T.I., Kutub-Zade T.K. O vozraste paleogenovykh nazimovskoy i khasanskoy svit YugoZapadnogo Primorya [About the age of the Paleogene Nazomova and Khasan formations in the southwestern Primorye]. Stratigrafiya. Geol. Korrelyatsiya, 2006, vol. 14, no. 3, pp. 108-121. 
7. Pavlyutkin B.I., Petrenko T.I. Stratigrafiva paleogen-neogenovykh otlozheniy Primorya [Stratigraphy of Paleogene-Neogene sediments in Primorye]. Vladivostok, Dalnauka Publ., 2010. 164 p.

8. Jackson S.E., Pearson N. J., Griffin W.L., Belousova E.A. The application of laser ablation-inductively coupled plasma-mass spectrometry to in situ $\mathrm{U} / \mathrm{Pb}$ zircon geochronology. Chemical Geology, 2004, vol. 211, pp. 47-69.

9. Khubanov V.B., Buyantuev M.D., Tsygankov A.A. U-PB dating of zircons from $\mathrm{PZ}_{3}-\mathrm{MZ}$ igneous complexes of Transbaikalia by sector-field mass spectrometry with laser sampling: technique and comparison with SHRIMP. Russian Geology and Geophysics, 2016, vol. 57, no. 1, pp. 190-205. In Rus.

10. Tsutsumi Y., Horie K., Sano T., Miyawaki R., Momma K., Matsubara S., Shigeoka M., Yokoyama K. LA-ICP-MS and SHRIMP age of zircons in chevkinite and monazite tuffs from the Boso Peninsula, Central Japan. Bulletin of the National Museum of Nature and Science. Series C, Geology \& Paleontology, 2012, vol. 38, pp. 15-32.

11. Chashchin S.A., Popov V.K., Chashchin A.A., Budnitskiy S.Yu. Novye rezultaty mineralogo-geokhimicheskikh i izotopnogeokhronologicheskikh issledovaniy triasovogo vulkanizma yuzhnogo Primorya (na primere izucheniya Talminskoy vulkanostruktury) [New results of mineralogical, geochemical and isotopegeochronological study of triassic volcanism in South Primorye (on the example of Talminsky volcanic structure)]. IX Sibirskaya konferenciya molodyh uchenyh po naukam o Zemle [IX Siberian Conference of Young Geoscientists]. Novosibirsk, 2018. pp. 673-676.

12. Gosudarstvennaya geologicheskaya karta Rossiyskoy Federatsii. Masshtab 1:200000. Seriya Khankayskaya. Listy K-52-XI, XVII. Obyasnitelnaya zapiska [State Geological Map of the Russian Federation, scale 1:200000. Khanka Formation. Pages K-52-XI, XVII with Legends]. Ed. by N.K. Tsesarskiy. Moscow, MF VSEGEI Publ., 2013. $144 \mathrm{p}$

13. Tanai T. Euphorbiaceae and Icacinaceae from the Paleogene of Hokkaido, Japan. Bulletin of the National Museum of Nature and Science. Series C, Geology \& Paleontology, 1990, vol. 16, no. 3, pp. 91-118.

14. Yabe A., Jeong E., Kim K., Uemura K. Oligocene-Neogene fossil history of Asian endemic conifer genera in Japan and Korea. Journal of Systematics and Evolution, 2019, vol. 57, no. 2, pp. 114-128.

15. Meyer H.W., Manchester S.R. The Oligocene Bridge Creek Flora of the John Day Formation, Oregon. University of California publications in geological sciences, 1997, vol. 141, $270 \mathrm{p}$.

16. Li Q., Su T., Liu Y.C., Quan C. Oligocene plant ecological strategies in low-latitude Asia unraveled by leaf economics. Journal of Asian Earth Sciences, 2019, vol. 182, no. 103933, pp. 1-10.
17. Tang H., Li S.-F., Su T., Spice R.A., Zhang S.-T., Li S.-H., Liu J., Lauretano V., Witkowski C.R., Spicer T.E.V., Deng W.-Y.-D., Wu M.-X., Ding W.-N., Zhou Z.-K. Early Oligocene vegetation and climate of southwestern China inferred from palynology. Palaeogeography, Palaeoclimatology, Palaeoecology, 2020, vol. 560, no. 109988, pp. 1-10.

18. Boytsova E.P., Panova L.A. Paleogenovye flory i rastitelnost na territorii Evraziyskoy botaniko-geograficheskoy oblasti [Evolution of the Paleogene flora on the territory of Eurasia]. Palinologiya kajnofita [Cenophytic Palynology]. Moscow, Nauka Publ., 1973. pp. 42-47.

19. Wang Q., Ferguson D.K., Feng G.-P., Ablaev A.G., Wang Y.-F., Yang J., Li Y.-L., Li C.-S. Climatic change during the Palaeocene to Eocene based on fossil plants from Fushun, China. Palaeogeography, Palaeoclimatology, Palaeoecology, 2010, vol. 295, pp. 323-331.

20. Meng Q.-t., Bruch A.A., Sun G., Liu Z.-j., Hu F., Sun P.-c. Quantitative reconstruction of Middle and Late Eocene paleoclimate based on palynological records from the Huadian Basin, northeastern China: Evidence for monsoonal influence on oil shale formation. Palaeogeography, Palaeoclimatology, Palaeoecology, 2018, vol. 510, pp. 63-77.

21. Zhao Y. Vegetation and climate reconstructions on different time scales in China: a review of Chinese palynological research. Vegetation History and Archaeobotany, 2018, vol. 27, pp. 381-392.

22. Wysocka A., Pha P.D., Durska E., Czarniecka U., Thang D.V., Filipek A., Cuong N.Q., Tuan D.M., Huyen N.X., Tha H.V., Staniszewski R. The Na Duong Basin (North Vietnam): a key for understanding Paleogene basin evolution in relation to the leftlateral Cao Bang-Tien Yen Fault. Journal of Asian Earth Sciences, 2020, vol. 195, no. 104350, pp. 1-20.

23. Mozherovsky A.V. Mineralogically based geology and stratigraphy of the Posyet peninsular (Southern Primorye). Bulletin of Kamchatka Regional Association «Educational-Scientific Center» Earth Sciences, 2019, vol. 43, no. 3, pp. 26-37. In Rus.

24. Popov V.K., Grebennikov A.V., Kovalenko S.V., Kutub-Zade T.K Petrologo-geokhimicheskaya kharakteristika vulkanicheskikh kaynozoyskikh kompleksov Kraskinskoy vpadiny na primere p-va Krabbe (Primorye) [Geochemical characteristics of Cenozoic igneous complexes of the Kraskino depression on the example of Krabbe Peninsular (Primorye)]. Mezozoyskie $i$ kaynozoyskie magmaticheskie $i$ metamorficheskie obrazovaniya Dalnego Vostoka. Materialy $V$ Dalnevostochnogo regionalnogo petrograficheskogo soveshchaniya [Mesozoic and Cenozoic magmatic and metamorphosed formations of the Far East. Proc. of the $\mathrm{V}^{\text {th }}$ Far Eastern Regional Petrographic Conference]. Khabarovsk, Khabarovskgeologiya Publ., 2001. pp. 38-40.

Received: 1 December 2021.

\section{Information about the authors}

Aleksandr A. Chashchin, Cand. Sc., senior research fellow, Far East Geological Institute FEB RAS.

Boris I. Pavlyutkin, Dr. Sc., leading research fellow, Far East Geological Institute FEB RAS.

Igor Yu. Chekryzhov, research fellow, Far East Geological Institute FEB RAS.

Valentin B. Khubanov, Cand. Sc., head of the laboratory, Geological Institute SB RAS.

Yukiyasu Tsutsumi, researcher, National Museum of Nature and Science.

Sergey A. Chashchin, junior research fellow, Far East Geological Institute FEB RAS. 